\title{
Value Added from the Perspective of Econophysics
}

\author{
Ihor Hurnyak (iD) https://orcid.org/0000-0003-0926-2456 \\ Associate Professor, Ivan Franko National University of Lviv, Faculty of International \\ Relations, Department of International Economic Analysis and Finance \\ Lviv, Ukraine, e-mail: hurnyakihor@gmail.com
}

\author{
Nataliya Struk (iD) https://orcid.org/0000-0002-1933-265X \\ D.Sc., Professor, Ivan Franko National University of Lviv, Faculty of Economics \\ Department of Accounting and Auditing, Lviv, Ukraine \\ e-mail: nataliya.struk@Inu.edu.ua
}

\section{Aleksandra Kordonska (iD) https://orcid.org/0000-0002-5316-9630 \\ Ph.D., University of Warmia and Mazury in Olsztyn, Institute of Political Science \\ Olsztyn, Poland, e-mail: aleksandra.kordonska@edukacja.uwm.edu.pl}

\section{Abstract}

The production, or value added, approach to GDP involves calculating an industry or sector's output and subtracting its intermediate consumption (the goods and services used to produce the output) to derive its value added. The value added at the macro level depends on business efficiency. It reflects an increase in value that a business creates by undertaking the production process. We assumed that the market creates thousands of vibrating energies, coming from other enterprises, with different frequencies. The purpose of this article is to verify whether the econophysics approach could be successfully used to assess a business from the perspective of the interaction between economic forces. Thus, we propose that the term 'value added' be understood as a certain amount of accumulated energy of enterprises that comes from the interaction of basic economic forces and economic vibrating forces of accounting. Using regression models, we show the influence of basic forces, like debt and the stock market, and vibrating ones (i.e., accounts payable, accounts receivable, inventory) on the economic value added by testing US, European, and emerging markets. We confirmed the relevance and appropriateness of the econophysics approach to estimating the economic value added. 
Ihor Hurnyak, Nataliya Struk, Aleksandra Kordonska

Keywords: accounting, business, economic forces, economic value added, econophysics

JEL: D02, D21, D25, D46, F21, F37, M21, M41

\section{Introduction}

The macroeconomic perspective of the value-added measure of GDP combines the value of output produced by each of the productive sectors in the economy. Therefore, value added is the increase in the value of goods or services as a result of the production process (the difference between the value of production and the value of intermediate goods). From a microeconomic perspective, the general definition of added value is proposed in the Dictionary of Business - "an amount added to the value of a product or service, equal to the difference between its cost and the amount received when it is sold. Wages, taxes, etc., are deducted from the added value to give the profit" (Collin 2004, p. 7). In other words, it is equivalent to the increase in value that a business creates by undertaking the production process. So, evaluating value added at the macro level should be implemented by considering a business's efficiency and accounting data.

Riahi-Belkaoui (1992, pp. 49-50) states that "value added refers to the increase in wealth generated by the productive use of the firm's resources before its allocation among shareholders, bondholders, workers, and the government. [...] the value added refers to the total return earned by the team of workers, capital providers, and the government." De Chernatony, Harris, and Dall'Olmo Riley (2000, p. 39) define value added as a "multidimensional construct, playing diverse roles, and interpreted in different ways by different people." Brandenburger and Stuart Jr. (1996, p. 5) propose a definition of the "value created by firms together with their suppliers and buyers." They identified four value added strategies based on the game theory models.

Meanwhile, the main aim of our research is to verify whether the econophysics approach could be successfully used to assess a business from the perspective of the interaction between economic forces.

Using Google Books Ngram Viewer (n.d.), we can assess the interest in studying value added. For comparison, we analyze such related terms as 'added value,' 'cash flow, and 'earnings quality.' An extremely strong interest is observed in 'cash flow' analysis; interest in 'value added' has grown in recent decades, while 'earnings quality' is rarely studied.

Some scholars even emphasize that the term 'added value' is losing its meaning. Moreover, in the system of Ukrainian national statistics, 'value added' is only formally an important measure of a country's development compared to other states (see: Hurnyak, Datsko, Yaremchuk 2015, pp. 37-47). Along with this, there are some attempts to implement this indicator in the system of financial and management accounting, 
although the concept of value added in a range of states like Ukraine at the sectoral, regional, and state levels is not clearly defined. Here, it is considered mainly as a basis of taxation and a result of economic activity. This approach is typical for the Central and Eastern Europe market as a whole. This interpretation is related to fiscal obligations, although they have led to other sources than human labor of value creation being neglected. Such a position can be validated by mercantilism, according to which the production of goods (and, consequently, value added) is focused on the creation and accumulation of wealth.

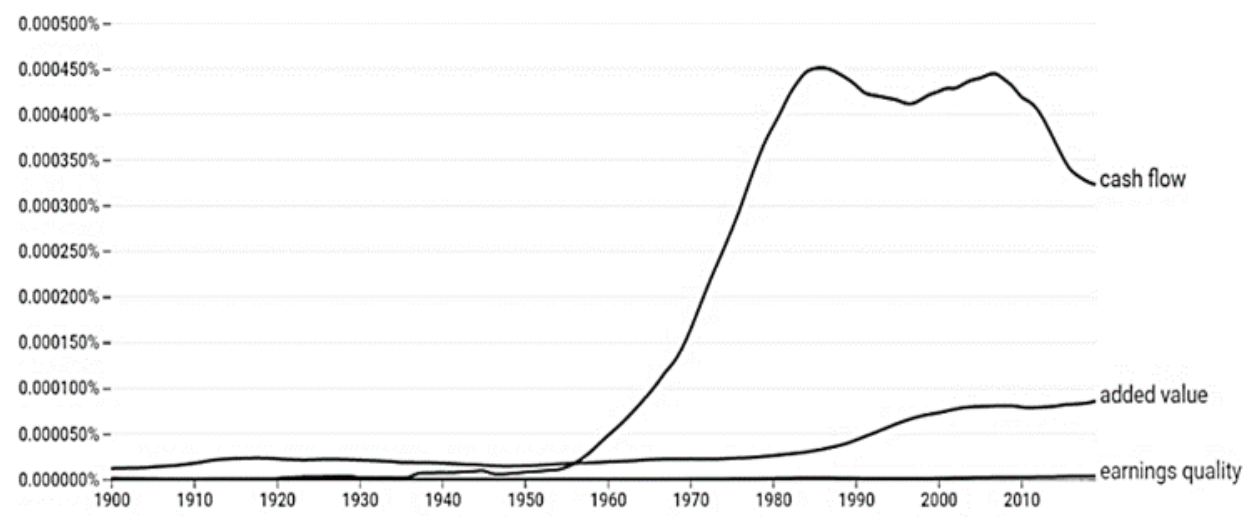

Figure 1. Search frequencies (\%) for the term 'added value,' 'cash flow,' and 'earnings quality' in sources printed between 1990 and 2018

Source: adapted from Google Books Ngram Viewer (n.d.).

\section{Theoretical review}

In the 1930s and 1940s, the concept of value added was actively discussed in Germany among scientists in the field of accounting. Meanwhile, the greatest success was achieved by French experts, who implement the calculation of value added in the General Accounting Plan (Fr. Plan comptable général). The modern approach assumes that accounting should provide information for enterprises as well as for national economic statistics. Therefore, attention should be paid to preparing a value added statement that contains information about the value added created by a business during the reporting period and how this value was distributed among participants (i.e., employees, government, owners, lenders) and reinvested in the business. The proposal of Suojanen (1954, pp. 391-398) to compile a value added statement as an appendix to the financial statements was implemented only after twenty years.

In the mid-1970s, such statements began to be published by companies in Great Britain, France, Germany, the Netherlands, Italy, Denmark, Switzerland, and South Africa, among others. They were prepared mainly by large companies, in particular: 
$26 \%$ of German, $19 \%$ of French, $30 \%$ of British, and 34\% of South African companies (Haller and Stolowy 1998, pp. 23-51; van Staden 1998, pp. 44-59). Nevertheless, since the 1980s, interest in value added reporting has decreased.

What is noteworthy is that we can observe the widespread use of this measure in the system of management accounting and also for fiscal purposes. Banerjee (2014, p. 23) states: "corporations in the US have started disclosing EVA (i.e., Economic Value Added) information from the beginning of 90 s as a measure of corporate performance. It is believed that market value of a firm (hence shareholder wealth) would increase with the increase in EVA." Chen adds, "Economic value added (EVA) is a measure of a company's financial performance based on the residual wealth calculated by deducting its cost of capital from its operating profit, adjusted for taxes on a cash basis. EVA can also be referred to as economic profit, as it attempts to capture the true economic profit of a company" (Chen 2020). Assessing a company's economic potential by using EVA allows for analysis of various economic indicators such as financial stability, investment attractiveness, competitiveness, solvency, and profitability, among others (Struk 2018, p. 267).

The approaches to calculating and presenting the value added in reporting differ. Some companies report gross value added by including depreciation, while others present a net value added (i.e., by excluding depreciation). Apart from this, calculating value added is made by various methods: [gross trading profit + gross margin + other operating costs purchased from third parties] or [operating profit + depreciation, amortization, and impairment losses on fixed assets + personal costs + tax other than corporate income tax] (Quiry et al. 2014).

Considering Parker's approach (1992, pp. 294-297) to value-added reporting, we can specify its advantages and disadvantages.

Advantages: the employees, government, lenders, and owners are considered to be stakeholders; the employees' attitudes towards the company can be improved thanks to the dissemination of value-added information; the report contributes to higher employee motivation; a number of useful coefficients can be calculated based on value-added information (e.g., the ratio of value added to employee wages); it makes it possible to assess the size and effectiveness of the company significantly better.

Disadvantages: a conflict of interest between participants may exist that contradicts their treatment as a team; users of reporting can be confused by a simultaneous increase in value added and a decrease in profit; a desirable maximization of value added can lead to an increase in production that results in higher risk to sell at a price below production costs; unlike in the case of the income statement, such a report is not integrated with the balance sheet (statement of financial position according to IFRS); the lack of a general method to calculate value added makes it difficult to compare the reports of different companies.

The further development of the concept of value added is related to the doctrine of sustainable development, which contains, inter alia, requirements for environmental protection, social justice, and the absence of racial and national discrimination. 
Managing sustainable development is impossible without a system of indicators that reflect the competitiveness of a business and its impact on the environment and society. For a long time, the most common practice for reporting sustainable development has been the Global Reporting Initiative. It offers three-dimensional reporting and reflects the activity by assessing environmental, social, and economic aspects. Thus, there are proposals to expand the financial statement by external costs and benefits related to the environmental, social, and economic aspects, which are not included in the traditional financial reporting (The Sigma Project 2003), and to introduce an extended value-added reporting on the following aspects (Mook 2007).

The main obstacle to implementing the proposed reporting is that the vast majority of environmental and social development characteristics cannot be reflected in monetary terms. Therefore, the concept of integrated reporting is dominant in modern times, according to which the company is interpreted as a mechanism for creating added value in the short, medium- and long-term periods of input resources (capital) in a certain way (business model) (Value Reporting Foundation 2013).

Many scientists have emphasized the importance of developing the financial markets due to the relationship between financial development and economic growth (see: Prats and Sandoval 2016). Scientists show the evidence of Granger causality between the stock market development and economic growth through an empirical analysis in Eastern Europe (Bulgaria, Slovakia, Hungary, Poland, the Czech Republic, and Romania) from 1995 to 2012. Furthermore, a number of participants who took part in the ECB workshop (Thimann 2002) for members of accession countries' central banks and the national central banks of the euro area agreed with the plausibility of a positive correlation between financial sector development and growth. They also remarked that the development of capital markets would possibly follow the strengthening of the banking sector, similar to the experience of several current EU Member States. "On the question of a choice or trade-off between a 'European' banking-based financial system and an 'Anglo-Saxon' market-based system, participants considered that this distinction should not be overemphasized as a relevant choice for accession countries. Priority at this stage was rather to establish a sound, stable and efficient banking sector" (Thimann 2002, p. 9). Meanwhile, we try to show and prove the importance of this institutional aspect without disclosing the details of such transformations.

Studying the diversification benefits to global investors, Baele, Bekaert, and Schäfer (2015, p. 30) found that "Central and Eastern European (CEE) markets have experienced similar trends as emerging markets more generally, with strongly increasing correlations with global benchmarks over time." They provided a comprehensive analysis of CEE equity markets from the mid-1990s until 2015 with global benchmarks over time. This also confirmed impossibility of narrowing our study just to the markets of Central and Eastern Europe, which are mainly included in emerging markets.

Ulfi Nur (2020) presented financial performance through the Economic Value Added (EVA) method in Mining Sector Public Companies listed on the IDX in 2014-2018 by using Invested Capital, Return on Invested Capital, and Weighted Average Cost 
of Capital. Meanwhile, Al-Afeef (2017, p. 141) showed that "there is no statistically significant effect of the economic value added (EVA) on changes in Stock Market Value of corporate shares that are under study during the period (2006-2015)". But the researcher addressed only a random sample of 46 companies.

De Wet and Hall (2004, pp. 39-59) emphasized: "[...] to maximize value for shareholders companies should strive towards maximizing MVA ${ }^{1}$ (and not necessarily their total market value). The best way to do so is 'to maximize the EVA.' [...] The leverage available to companies that incur fixed costs and use borrowed capital with a fixed interest charge has been known and quantified by financial managers for some time."

Maeenuddin, Akhtar, and Wajid Raza (2020) assessed firm performance with economic value added momentum rather than accounting-based profits. Researchers evaluated the cash conversion cycle based on three accounting ratios - creditor's turnover, debtor's turnover, and inventory turnover - based on non-financial firms listed on the Pakistan Stock Exchange for the period 2007-2016. The findings revealed that "firms with relatively lower (higher) days inventory turnover and days debtor turnover (days creditors turnover) results in lower cash conversion cycle and leads to higher EVA momentum. Results based on fixed effect model showed that components of WCM plays significant role in explaining the variation in EVA momentum and can be used to predict changes in EVA momentum" (sic) (Maeenuddin, Akhtar, and Wajid Raza 2020, p. 13845).

Vanacker et al. (2011, pp. 681-705) empirically investigated the relation between bootstrap strategies used at startup and subsequent venture growth using a longitudinal database that comprised data from questionnaires and financial accounts of 214 new ventures. The findings provide evidence of a consistently positive impact of financial bootstrapping on growth in value added across time. "More specifically, new ventures that use more owner funds, employ more interim personnel, encourage customers to pay more quickly, and apply for more subsidy programs exhibit higher growth over time." (Vanacker et al. 2011, p. 68).

As we can observe from the above discussion, modern studies are in line with our research. As supporters of theories of value added and this category as the basis of business efficiency, we consider the stock market not as a result but as a tool or economic force. The same applies to the banking market or, more generally, the debt market.

1 MVA = Market Value of Shares - Book Value of Shareholders' Equity. 


\section{The econophysics approach}

Nowadays, a considerable number of scholars have applied physics concepts and methods to understand economic phenomena. Notably, the distribution of returns in financial markets is studied the most intensively in that way (Mirowski 1989; Bouchaud and Cont 2002, pp. 543-550; Farmer and Joshi 2002, pp. 149-171; Sornette 2003). The approach is also used for studying the distribution of income and wealth (Levy and Solomon 1997, pp. 90-94; Drăgulescu and Yakovenko 2001, pp. 213-221; Chatterjee, Yarlagadda, and Chakrabarti 2005), the distribution of economic shocks and growth rate variations (Bak et al. 1993, pp. 3-30; Canning et al. 1998, pp. 335-341) and the distribution of firm sizes and growth rates (Stanley et al. 1996, pp. 804-806; Takayasu and Okuyama 1998, pp. 67-79). We would like to draw attention to the Theory of Monads proposed by Mykola Rudenko and Newtonian Microeconomics published by Mattie Estola, which states that physical tools may help investigate economic problems. According to Estola's approach (2017, p. 7), "the economic forces acting upon economic quantities are defined, and these forces explain the observed changes in economic quantities. This is a new framework of modeling in economics, and it is analogous to Newtonian mechanics in physics." He proposed replacing velocities of production values with annual value added of industries in the economy (Estola 2017, pp. 7, 88). Referring to the above concept, we would like to present different 'forces' that influence businesses by considering the macro-, meso- and micro levels (Figure 2).

Therefore, we propose that the term 'value added' be understood as a certain amount of accumulated energy of enterprises from the interaction of basic economic forces (i.e., a debt, stock market, a shadow economy, budget, etc.) and economic vibrating forces of accounting.

Figure 3 reflects our first simplified model for testing this approach. We suppose that the main forces in business are 'Debt' and 'Equity' like Gravity, Electro-Magnetism, Weak and Strong Nuclear in Physics. 'Equity' - 'Book Value of Equity' - refers to a firm or company's common equity - the amount available that can be distributed among the shareholders, and it is equal to the amount of assets owned by shareholders outright after all the liabilities have been paid off. Considering only the main forces, we cannot explain fully how the universe works, and respectively, we cannot explain all interactions in the economy only based on these 'forces.' The market creates thousands of vibrating energies that come from suppliers, buyers, competitors, and partners, with different frequencies (depending on the types of behavior). These vibrating forces influence any firm and are reflected in accounting, like accounts receivable (AR), inventory (I), accounts payable (AP), etc. Thus, increasing accounts receivable or inventory will shorten the distance between the company's debt and equity. Increasing accounts payable will expand the distance because it means that the enterprise has temporarily more funds for its activity and needs such resources from the outside less. If a company lacks resources for development, it can fall into the pit of surviving stability. The accumulation of equity and debt contributes to expanding and developing in terms of value added. 


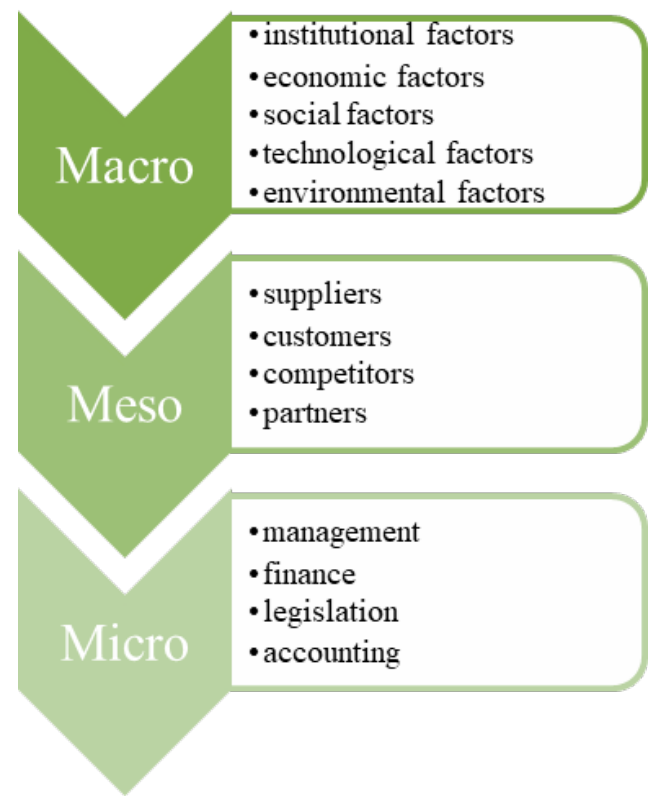

Figure 2. Macro-level, meso-level, and micro-level forces influencing business Source: authors' elaboration.

\section{Vibrating forces}

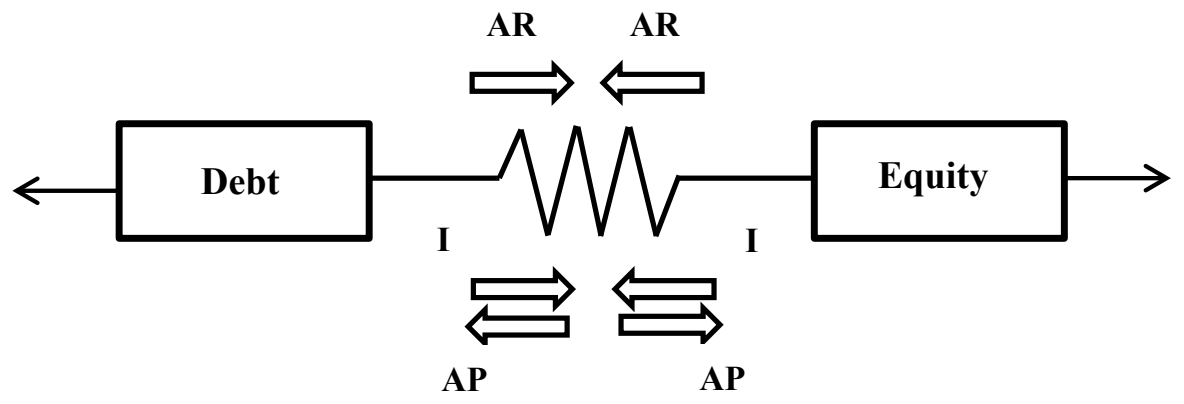

Figure 3. General simplified model of an enterprise's dynamic financial system Source: authors' elaboration.

Figure 4 presents a weak dynamic financial system of an enterprise in times of crisis, where a complex of vibrating forces has influenced the market the most. The purpose can be found in negative fluctuations on the banking and stock markets. Thus, in the first model (Figure 3), the economic forces act in one line along with the masses, which is defined as the level of inertia. ${ }^{2}$ Meanwhile, in model 2 (Figure 4), the market participants do not generate such significant masses due to their instability.

2 Newton's first law is called the law of inertia. The property of a body to remain at rest or to remain in motion with constant velocity is called inertia. The inertia of an object is measured by its mass. 


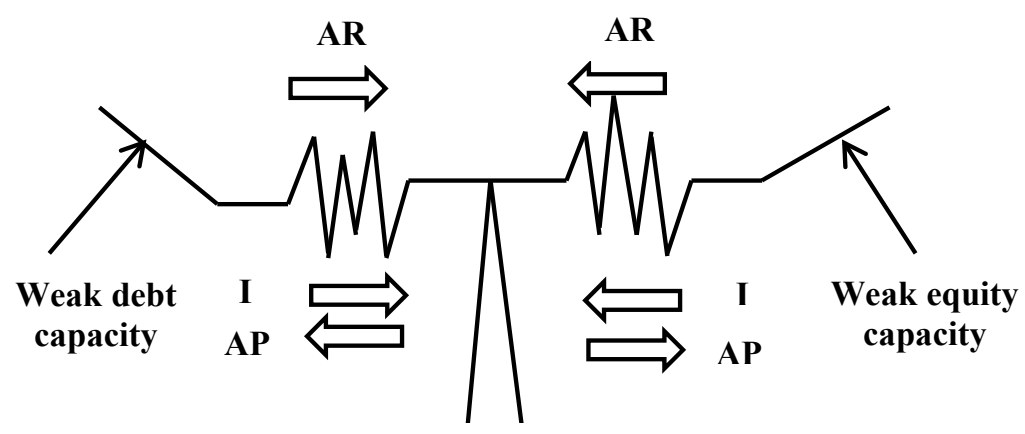

Vibrating forces

Figure 4. Simplified model of an enterprise's weak dynamic financial system in times of crisis Source: authors' elaboration.

Figure 5 presents an enterprise's dynamic financial system by taking into account forces that come from the vibrating activity on the stock and banking markets (e.g., zombie banking, financial bubbles, etc.). In a more general case, we have to expand the main forces with sources of capital that come from the shadow market and state (community) budget. Each of these forces will be influenced by weaker vibrating forces of a special nature.

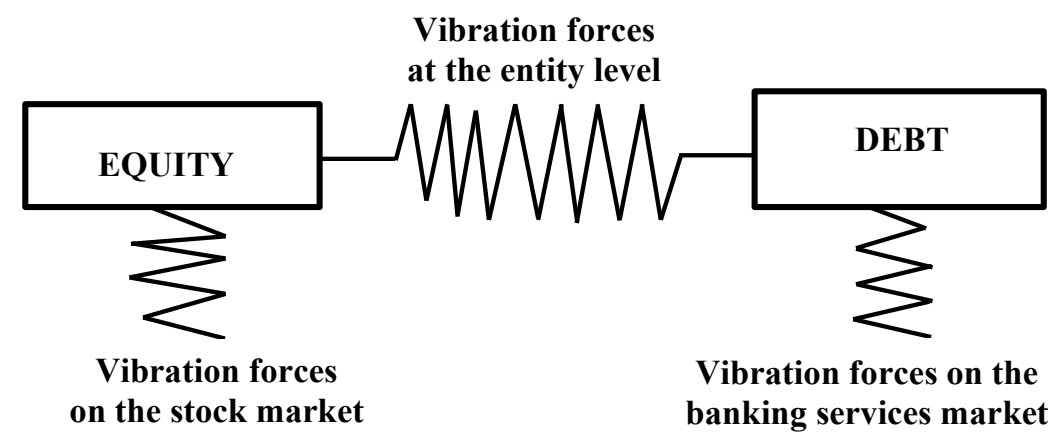

Figure 5. An extended market model of an enterprise's dynamic financial system Source: authors' elaboration.

\section{Methodology}

The general formula for calculating EVA is:

$$
[E V A=N O P A T-(\text { Invested Capital } * W A C C)],
$$

where: NOPAT - net operating profit after taxes, 


$$
\text { Invested capital }=D e b t+\text { capital leases }+ \text { sharholders' equity , }
$$

and WACC - weighted average cost of capital.

To test model 1 (Figure 3), we checked the impact of basic and vibrating forces on economic value added in the form of an equation (analogous to Newton's second law):

$$
m_{E V} \overrightarrow{E V}=\int_{0}^{T}\left(-m_{A P} \overrightarrow{A P}+m_{A R} \overrightarrow{A R}+m_{I} \vec{I}+m_{\text {Debt }} \overrightarrow{D e b t}+m_{\text {Equity }} \overrightarrow{\text { Equity })} d t,\right.
$$

where: $T$ - reporting period, $E V$ - economic value, $m_{E V} \overrightarrow{E V}$ - momentum (vector quantity that indicates the direction of movement), $m_{E V}$ - inertia of economic value, $m_{A P}$ - inertia of accounts payable, $m_{A R}$ - inertia of accounts receivable, $m_{I}$ - inertia of inventory, $m_{\text {Debt }}$ - inertia of debt, and $m_{\text {Equity }}$ - inertia of equity (book value of equity, $B V E)$. Meanwhile, accounts payable, accounts receivable, and inventory become vibrating forces that allow enterprises to operate their resources regardless of the basic forces. Notably, debt includes both short- and long-term debt (but not accounts payable and non-interest-bearing liabilities), while the book value of debt is used as a proxy for the market value of debt (according to Damodaran's approach). The circulation of funds in the accounts of the balance sheet during the reporting period is perceived as a process of integral calculation in mathematics and a method of transforming the energy coming from the financial markets into value added as a corresponding subintegral function. Once again, let us note that enterprise value $(E V)$ is a measure of a company's total value and includes in its calculation the market capitalization of a company but also its short- and long-term debt.

It is obvious to assume that the inertia of economic value and the level of gross sales (GS) have opposite directions (we also could avoid in this way potential scale effect), i.e., the bigger the sales, the smaller the level of inertia. Then, we rewrite the equation in a simpler linear form, assuming that the change of velocity of the economic value is economic value added.

$$
E V A=-\frac{k_{1}}{G S} A P+\frac{k_{2}}{G S} A R+\frac{k_{3}}{G S} I+k_{4} * B V C+k_{5},
$$

where $B V C$ - book value of capital (the book value of debt plus the book value of common equity, as reported on the balance sheet). We assumed that $m_{E V}=1$ or, in other words, rewriting the basic equation dividing all ingredients by $m_{E V}$. 


\section{Empirical findings and discussion}

Table 1 presents the results of testing the US, European, and emerging markets. ${ }^{3}$ Using the regression models, we showed the influence of the book value of capital, accounts payable, accounts receivable, and inventory on the economic value added in the US and emerging markets. Meanwhile, for the European markets, we applied the book value of equity due to the diversified influence of banking and stock markets on business in terms of the Anglo-Saxon and Continental models.

Table 1. The influence of main (book value of capital) and vibrating forces (i.e., accounts payable, accounts receivable, inventory) on the economic value added in the US, European, and emerging markets

\begin{tabular}{|c|c|c|c|c|}
\hline \multicolumn{5}{|c|}{ US market } \\
\hline Independent Variable & AR/GS & AP/GS & I/GS & BVC \\
\hline Beta & -0.183 & -0.018 & -0.171 & 0.676 \\
\hline Sign. & 0.064 & 0.836 & 0.088 & 0.000 \\
\hline VIF & 1.278 & 1.017 & 1.329 & 1.267 \\
\hline \multicolumn{5}{|c|}{$\begin{array}{l}\text { Note: } \text { Adjusted R-square = 0.333; F-statistic }=12.252(\text { Sign. }=0.000) . \\
\text { For constant: } t \text {-statistic }=3.156 ; \text { Sign. }=0.002 .\end{array}$} \\
\hline \multicolumn{5}{|c|}{ Emerging markets } \\
\hline Indicator/Variable & AR/GS & AP/GS & I/GS & BVC \\
\hline Beta & 0.08 & -0.192 & 0.017 & -0.827 \\
\hline Sign. & 0.053 & 0.000 & 0.491 & 0.000 \\
\hline VIF & 1.314 & 1.924 & 1.003 & 1.580 \\
\hline \multicolumn{5}{|c|}{$\begin{array}{l}\text { Note: } \text { Adjusted R-square }=0.883 ; \text { F-statistic }=175.895 \text { (Sign. }=0.000) \text {. } \\
\text { For constant: } t \text {-statistic }=2.089 ; \text { Sign. }=0.04\end{array}$} \\
\hline \multicolumn{5}{|c|}{ European market } \\
\hline Indicator/Variable & AR/GS & AP/GS & I/GS & BVE \\
\hline Beta & 0.138 & -0.494 & -0.046 & 0.233 \\
\hline Sign. & 0.205 & 0.000 & 0.560 & 0.047 \\
\hline VIF & 1.196 & 1.506 & 1.059 & 1.380 \\
\hline
\end{tabular}

Source: own elaboration based on a selected sample in 2018 (a total of 93 industries along with all necessary separate indicators and ratios for three different groups of markets) (Damodaran online n.d.).

Based on the regression models, we confirmed the relevance of the proposed approach to estimating the economic value added as a certain amount of accumulated energy coming from the interaction of basic and vibrating economic forces. The findings bring into question whether a value added is the result of (a) accounting 'manipulation,' in other words, the result of vibrating forces, (b) basic economic forces based on real investment in the stock, or (c) borrowing on the banking services market. Our findings of the univariate analysis seem to be successful by taking into account the ex-

3 According to $\mathrm{MSCl}$ (2020). 
planatory power of the regression model (the Adjusted R-square value), the statistical significance of the model (F-statistic), and the ratio of the departure of the estimated value of a parameter from its hypothesized value to its standard error ( $t$-statistic).

We found that in the US market, the basic economic forces are decisive and effective in terms of value added [Beta $\left.\mathrm{BVC}_{\mathrm{BV}}=0.676\right]$, in other words, by accumulating the firm's additional energy. As we can observe, the negative influence of vibrating forces, caused by using accounting 'manipulations,' is present, but it is not predominant $\left[\operatorname{Beta}_{\mathrm{AR} / \mathrm{GS}}=(-0.183) ; \operatorname{Beta}_{\mathrm{AP} / \mathrm{GS}}=(-0.018) ; \operatorname{Beta}_{\mathrm{I} / \mathrm{GS}}=(-0.171)\right]$. It is obvious that if the ratio between these indicators and sales is not maintained, such tools can be defined as manipulative, or such a situation is caused by a market crisis that is not covered by this model (Table 1 ).

In the case of emerging markets, we observe the influence of vibrating forces on the value added. Notably, the explanatory power of the regression model is $88.3 \%$, which means that the dependent variable (i.e., economic value added) largely depends on the proposed independent variables. We can assume that ineffective and undeveloped stock and bank capital markets do not contribute positively to the formation of additional energy of the business (they are even contrary to it), and they are significantly harmful to its functioning $\left[\right.$ Beta $\left._{\mathrm{BVC}}=-0.827\right]$. Thus, vibrating economic forces with an obvious accounting nature come to the fore $\left[\operatorname{Beta}_{\mathrm{AR} / \mathrm{GS}}=0.08 ; \operatorname{Beta}_{\mathrm{AP} / \mathrm{GS}}=-0.192 ; \operatorname{Beta}_{\mathrm{I} / \mathrm{GS}}=0.017\right.$ ] (Table 1, Figure 3). This can be explained by the banking sector concentrating on transactions with yielding government bonds, the phenomenon of zombie banking, or lending on non-market terms. We believe that emerging markets can be reflected by the model presented in Figure 4 .

In European markets, the situation is ambiguous. On the one hand, as with American markets, the influence of basic economic forces is significant and positive $\left[\right.$ Beta $\left._{\mathrm{BVC}}=0.233\right]$. It indicates that these markets are close to being sufficiently developed. On the other hand, this influence was significantly weaker than those of the vibrating forces. Thus, the available vibration forces outweighed the basic ones $\left[\operatorname{Beta}_{\mathrm{AR} / \mathrm{GS}}=0.138 ; \operatorname{Beta}_{\mathrm{AP} / \mathrm{GS}}=(-0.494) ;\right.$ Beta $\left._{\mathrm{I} / \mathrm{GS}}=(-0.046)\right]$. This can be explained by an other predominant type of corporate model compared to the United States.

Summing up, we can state that according to the data from 2018, the tightly regulated stock and banking markets in the US function much better in terms of generating additional business energy (value added) than European ones (Table 1). Taken separately in this case, the debt is not statistically significant. This model differs from the German banking pure one (traditionally popular in the past), with an emphasis on local interests and rapprochement with shareholders that requires other approaches and market interactions than those available in Europe earlier. Such analysis could also be made by taking into account the data from other years. At the same time, accounting indicators could be taken with a certain lag, for example, a year or a few years, and we can see how it will affect the value added in the particular year. We intend to use such an approach in future research. Meanwhile, this study was an attempt to present the possibility of reflecting the value added as a result of the interaction of economic forces, as well as the ability of such an approach to feed certain features of the business implementation mechanism. 


\section{Conclusions}

Nowadays, a majority of scientists agree that accounting should provide information for enterprises as well as for national economic statistics. Therefore, firms' preparation of a value-added statement that contains information about the value added created by the business during the reporting period, and how this value was distributed among participants and reinvested in the business, could be greatly significant when evaluating value added at the macro level. Meanwhile, there is a wide range of definitions due to the different approaches used to calculate and analyze value added. However, we consider using earnings quality as a tool for analysis to be ineffective because of the inconsistency between individual elements of the accounting system and the manipulation of reporting. This means that individual accounts should be the most appropriate for analysis rather than an aggregated summary data of financial statements. On the other hand, using value added just from the perspective of taxation, like in Ukraine, becomes another serious problem of inadequacy to the real state of business.

Within the frame of our empirical analysis and graphical simulations, we showed that the econophysics approach could be successfully used for assessing a business from the perspective of the interaction between economic forces by using financial indicators and transforming these financial levers into economic forces. Consequently, we have a reason to understand the added value as the energy created by a business based on the interactions of basic and vibrating forces. In fact, this study is the first attempt to present value added in such a way, which undoubtedly constitutes its contribution to economic theory.

The models proposed for testing the markets of the USA, Europe, and emerging markets confirmed the viability of the approach and make it possible to analyze the current state of value added (i.e., additional business energy). We revealed that the basic economic forces have a positive influence on value added in the US and European markets, indicating the sufficient development of these markets. But in European markets, this influence was significantly weaker than that of the vibrating forces. Meanwhile, we observed a high level of the explanatory power of the regression model in emerging markets and the strong influence of vibrating forces on business.

\section{References}

Al-Afeef, M. (2017), The Impact of Economic Value Added \& Return on Investment on the Changes in Stock Market's Value (Analytical Study: ASE: 2006-2015), "International Journal of Business and Management", 12 (10), pp. 132-142, https://doi .org/10.5539/ijbm.v12n10p132

Baele, L., Bekaert, G., Schäfer, L. (2015), An Anatomy of Central and Eastern European Equity Markets, "Columbia Business School Research Paper”, No. 15-71, https:// doi.org/10.2139/ssrn.2636900 
Bak, P., Chen, K., Scheinkman, J., Woodford, M. (1993), Aggregate fluctuations from independent sectoral shocks: self-organized criticality in a model of production and inventory dynamics, "Ricerche Economiche", 47 (1), pp. 3-30, https://doi.org/10.10 16/0035-5054(93)90023-V

Banerjee, R. (2014), SMEs, financial constraints and growth, "BIS Working Papers", No. 475, https://www.bis.org/publ/work475.pdf (accessed: 3.04.2021).

Bouchaud, J.P., Cont, R. (2002), A Langevin approach to stock market fluctuations and crashes, "European Physical Journal B", 6, pp. 543-550, https://doi.org/10.1007/s1 00510050582

Brandenburger, A.M., Stuart Jr., H.W. (1996), Value based business strategy, "Journal of Economics and Management Strategy", 5 (1), pp. 5-24, https://doi.org/10.1111 /j.1430-9134.1996.00005.x

Canning, D., Amaral, L.A.N., Lee, Y., Meyer, M., Stanley, H.E. (1998), A power law for scaling the volatility of GDP growth rates with country size, "Economics Letters", 60, pp. 335-341.

Chatterjee, A., Yarlagadda, S., Chakrabarti B.K. (eds.) (2005), Econophysics of Wealth Distributions, Springer, Milan.

Chen, J. (2020), Economic Value Added (EVA), Investopedia, https://www.investoped ia.com/terms/e/eva.asp (accessed: 19.04.2021).

Chernatony, L. de, Harris, F., Dall'Olmo Riley F. (2000), Added value: Its nature, roles and sustainability, "European Journal of Marketing”, 34 (1/2), pp. 39-56, https:// doi.org/10.1108/03090560010306197

Collin, P.H. (2004), Dictionary of Business, Fourth Edition, A\&C Black Publishers Ltd, London.

Damodaran online, http://pages.stern.nyu.edu/ adamodar/ (accessed: 5.03.2021).

Drăgulescu, A.A., Yakovenko, V.M. (2001), Exponential and power-law probability distributions of wealth and income in the United Kingdom and the United States, "Physica A", 299, pp. 213-221, http://physics.umd.edu/ yakovenk/papers/PhysicaA -299-213-2001.pdf (accessed: 5.03.2021).

Estola, M. (2017), Newtonian Microeconomics, Springer, New York, https://doi.org/10 $.1007 / 978-3-319-46879-2$

Farmer, J.D., Joshi, S. (2002), The price dynamics of common trading strategies, "Journal of Economic Behavior and Organization", 49, pp. 149-170, https://sites.santafe .edu/ jdf/papers/pricedynamics.pdf (accessed: 9.04.2021).

Google, Books Ngram Viewer, https://books.google.com/ngrams (accessed: 9.04.2021).

Haller, A., Stolowy, H. (1998), Value Added in financial accounting: a comparative study between Germany and France, "Advances in International Accounting", 11 (1), pp. 23-51.

Hurnyak, I.L., Datsko, O.I., Yaremchuk, O.I. (2015), Dodana wartist' jak bazys ekonomicznoho rozwytku terytorialnych hromad, "Rehionalna ekonomika", 1, p. 37-47, http://nbuv.gov.ua/UJRN/regek_2015_1_6 (accessed: 7.04.2021).

Levy, M., Solomon, S. (1997), New evidence for the power-law distribution of wealth, "Physica A", 242 (1-2), pp. 90-94, https://doi.org/10.1016/S0378-4371(97)00217-3

Maeenuddin, K., Akhtar, A., Wajid Raza, M. (2020), Impact of Working Capital Management on Firm's Economic Value Added Momentum, “Test Engineering \& Man- 
agement”, 82, pp. 13845-13855, https://www.academia.edu/42897401/Impact_of _Working_Capital_Management_on_Firms_Economic_Value_Added_Momen tum (accessed: 9.04.2021).

Mirowski, P. (1989), More Heat than Light: Economics as Social Physics, Cambridge University Press, Cambridge.

Mook, L.I. (2007), Social and Environmental Accounting: The Expanded Value Added Statement, University of Toronto, Toronto.

MSCI (2020), MSCI Global Market Accessibility Review, https://www.msci.com/docu ments/1296102/1330218/MSCI_2020_Global_Market_Accessibility_Review_Repo rt.pdf/78a73a91-af3d-cf21-94e8-1cc2c159d2ce (accessed: 3.04.2021).

Parker, R.H. (1992), Dictionary of Accounting, The Macmillan Press Ltd., London.

Prats, M.A., Sandoval, B. (2016), Stock Market and Economic Growth in Eastern Europe, "Economics Discussion Papers", No. 2016-35, Kiel Institute for the World Economy, Kiel.

Quiry, P., Dallocchio, M., Le Fur, Y., Salvi, A.(2014), Corporate Finance. Theory and Practice, Wiley, Chichester.

Riahi Belkaoui, A. (1992), Ahmed Value added reporting. Lessons for the United States, Quorum Books, New York-Westport-London.

Sornette, D. (2003), Why Stock Markets Crash: Critical Events in Complex Financial Systems, Princeton University Press, Princeton.

Staden, C.J. van (1998), The usefulness of the value-added statement in South Africa, "Managerial Finance", 24 (11), pp. 44-59, https://doi.org/10.1108/0307435981076 5705.

Stanley, M.H.R., Amaral, L.A.N., Buldyrev, S.V., Havlin, S., Leschhorn, H., Maass, P., Salinger, M.A., Stanley, H.E. (1996), Scaling behavior in the growth of companies, "Nature", 379, pp. 804-806, https://amaral.northwestern.edu/media/publication_pd fs/Stanley-1996-Nature-379-804.pdf (accessed: 9.04.2021).

Struk N.S. (2018), Teoretyko-metodołohiczni zasady j orhanizacija oblikowoji systemy diłowoho partnerstwa pidpryjemstw, POSWIT, Drohobycz.

Suojanen, W.W. (1954), Accounting theory and the large corporation, "Accounting Review”, 29 (3), p. 391-398, https://www.jstor.org/stable/241556?refreqid=excelsior \%3A6d51fd1c132a4dadc66462492159aa56 (accessed: 9.04.2021).

Takayasu, H., Okuyama, K. (1998), Country dependence on company size, distributions and a numerical model based on competition and cooperation, "Fractals", 6 (1), pp. 67-79, https://doi.org/10.1142/S0218348X98000080

The SIGMA Project (2003), The Sigma Guidelines-toolkit. Sustainability Accounting Guide, https://www.sustainabilityexchange.ac.uk/files/sigmaguidetosd.pdf (accessed: 18.03.2021).

Thimann, Ch. (2002), Financial Sectors in EU Accession Countries, European Central Bank, Kern \& Birner GmbH + Co, Frankfurt am Main.

Ulfi Nur, K. (2020), Analisis Kinerja Economic Value Added Padaperusahaan Publik Sektor Pertambangan Di Beiperiode 2014-2018, https://www.academia.edu/44111 664/ (accessed: 17.04.2021).

Value Reporting Foundation (2013), The International Integrated Reporting Framework, http://www.theiirc.org/ (accessed: 7.04.2021). 
Vanacker, T., Manigart, S., Meuleman, M., Sels, L. (2011), The Impact of Financial Bootstrap Strategies on Value Added in New Ventures: A Longitudinal Study, "Entrepreneurship \& Regional Development”, 23 (9-10), pp. 681-705, https://doi.org/10.1080 /08985626.2010.502250

Wet, J.H. de, Hall, J.H. (2004), The relationship between EVA, MVA and leverage, "Meditari Accountancy Research", 12 (1), pp. 39-59, https://doi.org/10.1108/102225292 00400003

\section{Wartość dodana z perspektywy ekonofizyki}

PKB liczony metodą produkcyjną jest to suma wartości dodanej ze wszystkich gałęzi produkcji narodowej po odjęciu wartości dóbr pośrednich. Wartość dodana na poziomie makro zależy od efektywności biznesu - odzwierciedla bowiem wzrost wartości dóbr wytworzonych przez przedsiębiorstwa. Zgodnie z założeniami, rynek generuje tysiące wibrujących energii o różnych częstotliwościach, pochodzących od innych przedsiębiorstw. Celem niniejszego opracowania jest zatem zbadanie możliwości wykorzystania ekonofizyki jako podejścia do oceny biznesu z punktu widzenia interakcji pomiędzy siłami ekonomicznymi. W związku z tym, zaproponowaliśmy rozumieć pod pojęciem „wartość dodana” pewną ilość energii skumulowanej przedsiębiorstw pochodzącej z interakcji podstawowych sił ekonomicznych i sił wibrujących (informacji przedstawionych w sprawozdaniu finansowym). W drodze modelowania regresyjnego ujawniliśmy wpływ podstawowych sił (tj. dług i rynek finansowy) oraz wibrujących (tj. zobowiązania, należności, zapasy) na ekonomiczną wartość dodaną, poddając analizie rynek Stanów Zjednoczonych, Europy oraz rynki wschodzące. Otrzymane wyniki potwierdzają trafność i stosowność wykorzystania ekonofizyki jako podejścia do szacowania ekonomicznej wartości dodanej.

Słowa kluczowe: rachunkowość, biznes, siły ekonomiczne, ekonomiczna wartość dodana, ekonofizyka

\begin{tabular}{|l|l|}
\hline \multirow{2}{*}{ C. C) by the author, licensee Łódź University - Łódź University Press, } \\
Łódź, Poland. This article is an open access article distributed under \\
the terms and conditions of the Creative Commons Attribution \\
license CC-BY-NC-ND 4.0 \\
(https://creativecommons.org/licenses/by-nc-nd/4.0/) \\
\cline { 2 - 2 } Received: 2021-01-27. Verified: 2021-07-09. Accepted: 2021-08-16. \\
\hline
\end{tabular}

